\title{
Kesehatan Reproduksi Remaja Putri di Pondok Pesantren Sidoarjo Jawa Timur
}

\author{
Queen Khoirun Nisa Mairo, ${ }^{1}$ Sri Endah Rahayuningsih, ${ }^{2}$ Benny Hasan Purwara ${ }^{3}$ \\ ${ }^{1}$ Prodi D3 Kebidanan Kampus Sutomo Jurusan Kebidanan Politeknik Kesehatan Kemenkes Surabaya, \\ ${ }^{2}$ Departemen Ilmu Kesehatan Anak Fakultas Kedokteran, ${ }^{3}$ Departemen Obstetri dan Ginekologi Fakultas \\ Kedokteran, Universitas Padjajaran/Rumah Sakit Dr. Hasan Sadikin Bandung
}

\begin{abstract}
Abstrak
Pada saat masa remaja terjadi proses kematangan organ reproduksi. Hal ini akan memunculkan masalah terkait kesehatan reproduksinya. Remaja lebih banyak menghabiskan waktunya di sekolah. Pondok pesantren merupakan model pendidikan yang bercirikan asrama dengan pola interaksi 24 jam dengan teman sebaya. Penelitian ini bertujuan menganalisis faktor yang berhubungan dengan kesehatan reproduksi remaja putri di pondok pesantren. Penelitian ini dilakukan pada 100 remaja putri Pondok Pesantren Darul Falah Pusat pada kurun waktu September-Oktober 2012 dengan menggunakan kuesioner yang telah teruji validitas dan reliabilitasnya. Variabel pengetahuan, sikap, komunikasi orangtua, komunikasi guru, komunikasi teman sebaya, dan sumber informasi sebagai independen, sedangkan kesehatan reproduksi sebagai dependen. Data dianalisis secara univariabel, bivariabel, dan multivariabel. Hasil penelitian menunjukkan remaja yang bermasalah dalam kesehatan reproduksi sebanyak 68\%. Kesehatan reproduksi remaja terdapat hubungan bermakna dengan faktor pengetahuan $(p=0,022)$, sikap $(p=0,002)$ dan komunikasi teman sebaya $(p<0,001)$, tetapi tidak terdapat hubungan bermakna terhadap kesehatan reproduksi remaja pada komunikasi orangtua $(\mathrm{p}=0,655)$, komunikasi guru $(\mathrm{p}=0,833)$, dan sumber informasi $(\mathrm{p}=0,532)$. Faktor yang paling berhubungan dengan kesehatan reproduksi remaja putri di pondok pesantren adalah komunikasi teman sebaya $(\mathrm{p}=0,001)$. Simpulan, masalah kesehatan reproduksi di pondok pesantren masih tinggi dengan pengetahuan mengenai kesehatan reproduksi masih rendah, sikap terhadap kesehatan reproduksi kurang, dan faktor yang paling berhubungan adalah komunikasi teman sebaya. [MKB. 2015;47(2):77-83]
\end{abstract}

Kata kunci: Kesehatan reproduksi remaja, lingkungan, pengetahuan, pondok pesantren, sikap

\section{Reproductive Health of Adolescent Girls in Islamic Boarding School Sidoarjo East Java}

\begin{abstract}
Reproductive organ maturation process in adolescence is often prone to health issues. Adolescents spend more time in school, especially when they study in an islamic boarding school. Islamic boarding school is an educational model which is characterized by a dorm with 24 hour interaction pattern among peers. This study aimed to analyze factors associated with adolescent reproductive health in Islamic boarding school female students. This study was conducted on 100 adolescent girls in Darul Falah Center Islamic boarding school during September to October 2012 using questionnaires with proven validity and reliability. Knowledge, attitudes, parent communication, teacher communication, peer communication, source of information were used as the independent variables and reproductive health was used as the dependent variable. All variables were analyzed ini univariabel, bivariable, and multivariable manners. The results of this study show that $68 \%$ adolescents had reproductive health problems. There was a significant relationship between knowledge $(p=0.022)$, attitude $(p=0.002)$ and peers communication $(p<0.001)$ factors and adolescent reproductive health with no significant relationship discovered between the reproductive health of adolescents and parent communication ( $p=0.655)$, teacher communication $(p=0.833)$, and sources of information ( $\mathrm{p}=0.532$ ). The most influencing factor associated with reproductive health in adolescent girls Islamic boarding school was peer communications $(\mathrm{p}=0.001)$. In conclusions, reproductive health problem in Islamic boarding school remains high with inadequate knowledge of reproductive health and low attitude towards reproductive health with peer communication as the most influencing factor. [MKB. 2015;47(2):77-83]
\end{abstract}

Key words: Adolescent reproductive health, attitudes, environment knowledge, Islamic boarding school

Korespondensi: Queen Khoirun Nisa Mairo, M.Keb, Prodi Kebidanan Sutomo Jurusan Kebidanan Politeknik Kesehatan Kemenkes Surabaya Jalan Prof. Mustopo 8 A Surabaya, Telepon: (031) 5027404, mobile 081332266707, e-mail: queenmairo13@gmail.com 


\section{Pendahuluan}

Masa remaja merupakan masa peralihan antara masa anak-anak menuju masa dewasa yang diawali dengan terjadi kematangan seksual. Remaja akan dihadapkan pada keadaan yang memerlukan penyesuaian untuk dapat menerima perubahan yang terjadi pada dirinya. Kematangan seksual dan perubahan bentuk tubuh sangat berpengaruh pada kehidupan kejiwaan remaja. Kematangan seksual juga dapat mengakibatkan remaja-remaja mulai tertarik terhadap anatomi fisiologi tubuhnya, juga mulai muncul perasaan tertarik kepada teman sebaya yang berlawanan jenis. ${ }^{1}$ Remaja di Indonesia saat ini sedang mengalami peningkatan kerentanan terhadap berbagai ancaman risiko kesehatan terutama yang berkaitan dengan kesehatan seksual dan reproduksi. ${ }^{2}$ Masa remaja rentan mengalami masalah serta berperilaku risiko tinggi, seperti pengalahgunaan dan ketergantungan narkotika, alkohol dan zat adiktif, melakukan seks bebas, kekerasan, dan lain-lain. ${ }^{3}$

Berbagai masalahyangada pada remaja sangat rentan terhadap kesehatan reproduksi. World Health Organization (WHO) mendefinisikan bahwa kesehatan reproduksi merupakan suatu keadaan fisik dan mental serta sosial yang utuh, bukan hanya bebas dari penyakit atau kecacatan dalam segala aspek yang berhubungan dengan sistem reproduksi, fungsi, serta prosesnya. Sehat secara reproduksi merupakan suatu keadaan manusia dapat menikmati kehidupan seksualnya dan mampu menjalankan fungsi serta proses reproduksinya secara sehat dan aman. ${ }^{1}$

Sebagian besar remaja berada di sekolah sehingga sekolah menjadi salah satu tempat memperoleh pendidikan, termasuk pendidikan kesehatan reproduksi, seksualitas, dan perilaku kesehatan. Salah satu model pendidikan yang ada di Indonesia adalah pondok pesantren, suatu tempat pendidikan dan juga pengajaran yang menekankan pada pelajaran agama Islam dan didukung asrama sebagai tempat tinggal santri. Pondok pesantren memiliki tiga kategori, yaitu tradisional, modern, dan perpaduan. Sebagian besar warga pondok pesantren adalah santri, yaitu remaja yang berusia 9-20 tahun dengan kategori santri mukim, yaitu santri yang menetap dan santri kalong, yaitu santri yang hanya datang saat-saat waktu mengaji. ${ }^{4}$

Remaja berinteraksi selama 24 jam di pondok pesantren dengan komunitas teman usia sebaya. Masalah kesehatan di pondok pesantren masih memerlukan perhatian dari berbagai pihak yang terkait, baik dalam akses pelayanan kesehatan, perilaku sehat, maupun kesehatan lingkungan. Berdasarkan penelitian Ma'rufi dkk. ${ }^{5}$ pada 6 pondok pesantren di Jawa Timur memberikan hasil $64,20 \%$ santri menderita penyakit skabies, $73,70 \%$ santri memiliki higiene perorangan yang buruk, perilaku sering memakai baju atau handuk bergantian dengan teman, dan masih banyak ditemui sanitasi lingkungan pondok pesantren yang kurang baik sehingga hal tersebut akan sangat berpengaruh pada kesehatan reproduksi remaja. Berbagai masalah yang terjadi di pondok pesantren akan memengaruhi kesehatan reproduksi para santri selaku remaja yang tinggal di Pondok Pesantren itu. Kesehatan reproduksi remaja banyak dipengaruhi oleh berbagai faktor, baik faktor internal maupun faktor eksternal. Faktor internal yaitu pengetahuan dan sikap, sedangkan faktor eksternal yaitu lingkungan yang meliputi lingkungan keluarga, guru, dan teman sebaya, serta sumber informasi mengenai kesehatan reproduksi.

Di Indonesia, terdapat pondok pesantren sejumlah 14.798. Berdasarkan data Kementrian Agama RI tahun 2009, di Jawa Timur terdapat 5.025 pondok pesantren serta di Kabupaten Sidoarjo sebanyak 208 pondok pesantren. Darul Falah Pusat ialah merupakan salah satu pondok pesantren yang terdapat di Kabupaten Sidoarjo, tepatnya di Kecamatan Krian. Pondok pesantren ini merupakan tipe tradisional dengan pola pembelajaran sekolah diniyah atau sekolah kitab klasik, dengan pembelajaran terpisah antara santri putra dan putri. Pondok Pesantren Darul Falah ini terletak di pinggir Kota Surabaya dan sekitar $3 \mathrm{~km}$ ada pelayanan kesehatan berupa rumah sakit. Pesantren ini tidak mempunyai Pos Kesehatan Pesantren (Poskestren), tetapi mempunyai klinik pengobatan dalam proses pembangunan.

\section{Metode}

Penelitian ini menggunakan penelitian potong lintang, observasional analitik, dilakukan pada September-Oktober 2012. Subjek penelitian ini adalah remaja putri di Pondok Pesantren Darul Falah Pusat Krian, Sidoarjo, Jawa Timur dengan kriteria inklusi usia 14-18 tahun dan menetap di pondok pesantren. Untuk mengukur kesehatan reproduksi remaja dipakai kuesioner dari pedoman teknis penjaringan kesehatan remaja anak sekolah lanjutan yang dikeluarkan oleh Direktorat Bina Kesehatan Masyarakat (Binkesmas), sedangkan pengetahuan, sikap, dan lingkungan (komunikasi orangtua, komunikasi 
Tabel 1 Definisi Operasional Variabel, Alat Ukur, Hasil Ukur, dan Skala Pengukurannya

\begin{tabular}{|c|c|c|c|c|}
\hline Variabel & Definisi Operasional & Alat Ukur & Hasil Ukur & Skala \\
\hline \multicolumn{5}{|l|}{ Variabel bebas } \\
\hline Pengetahuan & $\begin{array}{l}\text { Pemahaman remaja terhadap } \\
\text { hal yang berkaitan dengan } \\
\text { Kesehatan Reproduksi: } \\
\text { 1. definisi kesehatan } \\
\quad \text { reproduksi, } \\
\text { 2. organ reproduksi, } \\
\text { 3. menstruasi, } \\
\text { 4. masa subur, } \\
\text { 5. kehamilan, } \\
\text { 6. metode kontrasepsi, } \\
\text { 7. HIV/AIDS dan IMS, }\end{array}$ & Kuesioner & $\begin{array}{l}\text { 2. Tinggi } \\
\quad(\text { skor } \geq 75 \%) \\
\text { 1. Rendah } \\
\quad(\text { skor }<75 \%)\end{array}$ & Ordinal \\
\hline Sikap & $\begin{array}{l}\text { Tanggapan remaja terhadap } \\
\text { kesehatan reproduksi dan } \\
\text { seksualitas }\end{array}$ & Kuesioner & $\begin{array}{l}\text { Katerogi penilaian: } \\
\mathrm{SS}=5 \\
\mathrm{~S}=4 \\
\mathrm{RR}=3 \\
\mathrm{TS}=2 \\
\mathrm{STS}=1 \\
\text { 2. Tinggi } \\
\quad \text { (skor } \geq 75 \% \text { ) } \\
\text { 1. Rendah } \\
\quad \text { (skor }<75 \% \text { ) }\end{array}$ & Ordinal \\
\hline $\begin{array}{l}\text { Komunikasi } \\
\text { orangtua }\end{array}$ & $\begin{array}{l}\text { Komunikasi remaja dengan } \\
\text { orangtua mengenai kesehatan } \\
\text { reproduksi }\end{array}$ & Kuesioner & $\begin{array}{l}\text { 2. Komunikasi baik } \\
\text { ( } \geq \text { skor median) } \\
\text { 1. Komunikasi buruk } \\
(<\text { skor median) }\end{array}$ & Nominal \\
\hline \multicolumn{5}{|l|}{ Variabel terikat } \\
\hline Komunikasi Guru & $\begin{array}{l}\text { Komunikasi remaja dengan } \\
\text { guru/ustadah mengenai } \\
\text { kesehatan reproduksi }\end{array}$ & Kuesioner & $\begin{array}{l}\text { 2. Komunikasi baik } \\
\text { ( } \geq \text { skor median) } \\
\text { 1. Komunikasi buruk } \\
(<\text { skor median) }\end{array}$ & Nominal \\
\hline $\begin{array}{l}\text { Komunikasi teman } \\
\text { sebaya }\end{array}$ & $\begin{array}{l}\text { Pengaruh teman sebaya yang } \\
\text { dapat melalui komunikasi } \\
\text { mengenai kesehatan } \\
\text { reproduksi }\end{array}$ & Kuesioner & $\begin{array}{l}\text { 2. Komunikasi baik }(\geq \\
\text { skor median) } \\
\text { 1. Komunikasi buruk }(< \\
\text { skor median) }\end{array}$ & Nominal \\
\hline Sumber informasi & $\begin{array}{l}\text { Asal informasi tentang } \\
\text { kesehatan reproduksi yang } \\
\text { dapat dari: } \\
\text { 1. koran, } \\
\text { 2. majalah, } \\
\text { 3. kitab-kitab klasik, } \\
\text { 4. radio, } \\
\text { 5. televisi, } \\
\text { 6. internet, } \\
\text { 7. guru/ustadz, } \\
\text { 8. orangtua, } \\
\text { 9. teman sebaya, } \\
\text { 10. tenaga kesehatan } \\
\text { lain-lain. }\end{array}$ & Kuesioner & $\begin{array}{l}\text { 2. Mendapat sumber } \\
\text { informasi baik } \\
\text { ( } \geq \text { skor median) } \\
\text { 1. Sumber informasi } \\
\text { kurang (< skor } \\
\text { median) }\end{array}$ & Nominal \\
\hline $\begin{array}{l}\text { Kesehatan } \\
\text { reproduksi remaja }\end{array}$ & $\begin{array}{l}\text { Keadaan sehat secara } \\
\text { reproduksi berdasarkan } \\
\text { penilaian menggunakan } \\
\text { pedoman penjaringan } \\
\text { kesehatan remaja dalam PKPR }\end{array}$ & Kuesioner & $\begin{array}{l}\text { 2. Tidak bermasalah } \\
(\text { skor }>5) \\
\text { 1. Bermasalah } \\
(\text { skor } \leq 5)\end{array}$ & \\
\hline
\end{tabular}


guru, komunikasi teman sebaya, dan sumber informasi) menggunakan modifikasi kuesioner dari Illustrative Questionnaire for InterviewSurveys with Young People dari WHO, dan Survei Kesehatan Reproduksi Remaja Indonesia dari Badan Pusat Statistik (BPS). Analisis univariabel dilakukan dengan distribusi frekuensi, analisis bivariabel dengan $c h i$-kuadrat $\left(\mathrm{X}^{2}\right)$, dan analisis multivariabel dengan regresi logistik.

\section{Hasil}

Selama periode penelitian ini terdapat 100 remaja yang memenuhi kriteria inklusi. Hasil berdasarkan kuesioner dan kriteria kesehatan reproduksi yang sudah ditetapkan ditemukan 68 remaja putri tergolong kategori bermasalah. Tidak ada perbedaan pada kedua kelompok dari segi karakteristik subjek, yaitu usia, berat badan, dan juga tinggi badan (Tabel 2). Usia responden mempunyai median 16 dengan rentang 14-18, berat badan responden memiliki nilai median 45 pada responden bermasalah dengan rentang 32-70 dan nilai median 46,5 pada responden tidak bermasalah dengan rentang 29-63. Tinggi badan responden memiliki nilai median 146 pada responden bermasalah dengan rentang 134-153 dan nilai median 144,5 pada responden tidak bermasalah dengan rentang 130-161. Terdapat hubungan yang bermakna kesehatan reproduksi remaja dengan faktor pengetahuan $(\mathrm{p}=0,022)$, sikap $(\mathrm{p}=0,002)$, dan komunikasi teman sebaya $(\mathrm{p}<0,001) \quad($ Tabel 3). Faktor komunikasi orangtua $(\mathrm{p}=0,655)$, komunikasi guru $(p=0,833)$, dan sumber informasi $(p=0,532)$ menunjukkan tidak ada hubungan bermakna dengan kesehatan reproduksi remaja. Hasil uji statistik multivariabel menggunakan regresi logistik memperlihatkan bahwa variabel yang memiliki hubungan bermakna dengan kesehatan reproduksi adalah sikap $(p=0,016)$ dan juga komunikasi teman sebaya $(p=0,001)$ sehingga variabel yang sangat memengaruhi kesehatan reproduksi remaja putri di pondok pesantren adalah komunikasi teman sebaya (Tabel 4).

\section{Pembahasan}

Secara umum di Pondok Pesantren Darul Falah, kesehatan reproduksi remaja bermasalah lebih tinggi yaitu 68\%. Banyak dari mereka yang memiliki masalah dalam siklus haid, keputihan, dan gatal-gatal pada area kelamin. Dari mereka yang bermasalah rata-rata berusia 16 tahun, keadaan ini memperkuat penelitian Tegegn dkk. ${ }^{6}$ yang menyatakan bahwa usia remaja putri yang memiliki masalah dalam kesehatan reproduksi adalah 16,87 (SD=1,49). Hal ini sejalan dengan penelitian Cahyo dkk. ${ }^{7}$ yang menyatakan bahwa pengetahuan dan praktik kesehatan reproduksi remaja mempunyai hubungan yang signifikan. Berdasar penelitian Bobhate dan Shrivastava ${ }^{8}$ memperlihatkan bahwa sebanyak $66 \%$ remaja putri memiliki pengetahuan yang benar tentang

\section{Tabel 2 Karakteristik Responden}

\begin{tabular}{lccc}
\hline Karakteristik Subjek & \multicolumn{3}{c}{ Kesehatan Reproduksi Remaja } \\
\cline { 2 - 4 } & $\begin{array}{c}\text { Bermasalah } \\
(\mathbf{n = 6 8})\end{array}$ & $\begin{array}{c}\text { Tidak Bermasalah } \\
(\mathbf{n = 3 2})\end{array}$ & $\mathbf{p}$ \\
\hline Usia (tahun) & & & 0,466 \\
$\quad$ Rata-rata (SD) & $16,1(1,2)$ & $15,9(1,2)$ & \\
$\quad$ Median & 16 & 16 & \\
$\quad$ Rentang & $14-18$ & $14-18$ & 0,151 \\
Berat badan (kg) & & & \\
Rata-rata (SD) & $44,9(6,6)$ & $46,7(7,1)$ & \\
Median & 45 & 46,5 & 0,781 \\
Rentang & $32-70$ & $29-63$ & \\
Tinggi badan (cm) & & & \\
Rata-rata (SD) & $144,8(4,6)$ & $145,7(7,3)$ & \\
Median & 146 & 144,5 & \\
$\quad$ Rentang & $134-153$ & $130-161$ & \\
& & & \\
\hline
\end{tabular}


Tabel 3 Faktor yang berhubungan dengan Kesehatan Reproduksi Remaja Putri di Pondok Pesantren

\begin{tabular}{|c|c|c|c|c|c|c|}
\hline \multirow{3}{*}{ Variabel } & \multicolumn{2}{|c|}{ Kesehatan Reproduksi } & \multirow{3}{*}{ Jumlah } & \multirow{3}{*}{$\%$} & \multirow{3}{*}{$\mathbf{X}^{2}$} & \multirow{3}{*}{$\mathbf{p}$} \\
\hline & Bermasalah & $\begin{array}{c}\text { Tidak } \\
\text { Bermasalah }\end{array}$ & & & & \\
\hline & $\mathbf{n}$ & $\mathbf{n}$ & & & & \\
\hline \multicolumn{7}{|l|}{ Pengetahuan } \\
\hline Rendah & 48 & 15 & 63 & 100 & 5,249 & 0,022 \\
\hline Tinggi & 20 & 17 & 37 & 100 & & \\
\hline \multicolumn{7}{|l|}{ Sikap } \\
\hline Rendah & 59 & 19 & 78 & 100 & 9,513 & 0,002 \\
\hline Tinggi & 9 & 13 & 22 & 100 & & \\
\hline \multicolumn{7}{|l|}{ Lingkungan } \\
\hline \multicolumn{7}{|l|}{ Komunikasi orangtua } \\
\hline Komunikasi jelek & 33 & 14 & 47 & 100 & 0,200 & 0,655 \\
\hline Komunikasi baik & 35 & 18 & 53 & 100 & & \\
\hline \multicolumn{7}{|l|}{ Komunikasi guru } \\
\hline Komunikasi jelek & 27 & 12 & 39 & 100 & 0,045 & 0,833 \\
\hline Komunikasi baik & 41 & 20 & 61 & 100 & & \\
\hline \multicolumn{7}{|c|}{ Komunikasi teman sebaya } \\
\hline Komunikasi jelek & 36 & 4 & 40 & 100 & 14,828 & $<0,001$ \\
\hline Komunikasi baik & 32 & 28 & 60 & 100 & & \\
\hline \multicolumn{7}{|l|}{ Sumber Informasi } \\
\hline Buruk & 30 & 12 & 42 & 100 & 0,391 & 0,532 \\
\hline Baik & 38 & 20 & 58 & 100 & & \\
\hline
\end{tabular}

Tabel 4 Hubungan Pengetahuan, Sikap, dan Lingkungan dengan Kesehatan Reproduksi Remaja Putri di Pondok Pesantren

\begin{tabular}{lcccc}
\hline \multicolumn{1}{c}{ Faktor } & Koef B & S.E (B) & p & RP (IK 95\%) \\
\hline Model awal & & & & \\
$\quad$ Pengetahuan & 0,897 & 0,566 & 0,113 & $2,43(0,81-7,43)$ \\
Sikap & 1,139 & 0,604 & 0,059 & $3,12(0,96-10,20)$ \\
Komunikasi orangtua & $-0,114$ & 0,524 & 0,827 & $0,89(0,32-2,49)$ \\
Komunikasi guru & 0,181 & 0,566 & 0,749 & $1,20(0,39-3,63)$ \\
Komunikasi teman & 2,000 & 0,617 & 0,001 & $7,39(2,21-24,75)$ \\
Sistem informasi & $-0,421$ & 0,604 & 0,481 & $0,00(0,20-2,14)$ \\
Model akhir & & & & \\
Sikap & 1,316 & 0,547 & 0,016 & $3,73(1,28-10,90)$ \\
Komunikasi teman sebaya & 1,948 & 0,600 & 0,001 & $7,01(2,16-22,73)$ \\
Konstanta & $-5,713$ & - & - & - \\
\hline
\end{tabular}


cara penularan human immunodeficiency virus (HIV) dan hanya 18,7\% yang mengetahui tentang praktik seksual yang aman. Remaja putri harus diberikan pengetahuan yang tepat mengenai kesehatan reproduksi, seksualitas, dan pubertas untuk membantu mereka menangani masalah kesehatan reproduksi mereka. Remaja perlu mendapatkan informasi yang cukup mengenai kesehatan reproduksi mereka sehingga remaja mengetahui hal yang seharusnya dilakukan dan dihindari. Pendidikan kesehatan reproduksi oleh para profesional kesehatan dapat meningkatkan pengetahuan remaja putri, sedangkan intervensi pendidikan harus diberikan untuk membantu remaja putri dalam menjaga kesehatan dan melindungi diri dari risiko infeksi menular seksual (IMS). ${ }^{9}$

Remaja putri yang ada di pondok pesantren mendapatkan pengetahuan mengenai kesehatan reproduksi dari kitab klasik seperti Adabul Mar'ah, Risalatul Mahid, Kitabun Nikah, Qurratul Uyun, Uqud al lujjayn, dan lain-lain. Kitab tersebut berisi hal-hal mengenai haid/menstruasi dan ketentuan syariat yang terkait, cara pergaulan dengan lawan jenis, persiapan pernikahan, dan sopan santun perempuan terhadap keluarganya terutama suaminya dan pendidikan akhlak.

Pendidikan kesehatan reproduksi memang sudah ada dalam pondokpesantren dengan model yang cenderung normatif untuk kepentingan ibadah dan pelaksanaan akhlak dalam keluarga dan pergaulan, akan tetapi pemahaman rasional seperti menstruasi dan cara menjaga kebersihan organ reproduksi belum diberikan. Hal ini yang menyebabkan pengetahuan mengenai kesehatan reproduksi remaja di pondok pesantren masih rendah.

Menurut Asfriyati dan Sanusi ${ }^{10}$ faktor sikaplah yang menentukan perilaku dalam kesehatan reproduksi remaja di pondok pesantren. Sikap dapat diuraikan sebagai penilaian seseorang terhadap stimulus atau objek. Sikap adalah suatu perasaan, predisposisi, atau seperangkat keyakinan yang relatif tetap terhadap suatu objek, seseorang, atau suatu situasi. Manifestasi sikap itu tidak dapat dilihat, tetapi dapat ditafsirkan lebih dulu. Sikap secara nyata menunjukkan konotasi kesesuaian reaksi terhadap stimulus tertentu yang di dalam kehidupan sehari-hari merupakan suatu reaksi yang bersifat emosional terhadap stimulus sosial.

Penelitian Asfriyati dan Sanusi ${ }^{10}$ pada remaja di pondok pesantren, sebagian besar remaja mempunyai hubungan atau komunikasi baik, akan tetapi semua responden menyatakan bahwa tidak pernah melakukan komunikasi mengenai kesehatan reproduksi dengan orangtua mereka. Sejalan dengan penelitian yang dilakukan oleh Cahyo dkk. ${ }^{7}$ pada remaja di sekolah menengah atas negeri, peranan guru dengan praktik kesehatan reproduksi remaja tidak mempunyai hubungan yang signifikan. Penelitian Suminar dkk. ${ }^{11}$ menyatakan lingkungan guru dengan perilaku dalam kesehatan reproduksi tidak mempunyai korelasi bermakna. Guru merupakan lingkungan yang dekat dengan remaja karena remaja banyak menghabiskan waktunya di sekolah. Di pondok pesantren hubungan guru yang biasa disebut ustad/ustadzah memiliki jarak karena ada adab atau sopan santun tersendiri yang berlaku dalam hubungan mereka seperti diterangkan dalam kitab Taklim Muta'alim yang sangat popular dan selalu dibahas dan diterapkan dalam pondok pesantren. Remaja masih menganggap sangat tabu bila membicarakan hal seperti kesehatan reproduksi dengan guru di pondok pesantren.

Sejalan dengan penelitian Suminar dkk. ${ }^{11}$ yang memperlihatkan bahwa lingkungan temanteman sebaya dengan perilaku dalam kesehatan reproduksi memiliki korelasi bermakna. Remaja ternyata lebih senang, nyaman, dan juga terbuka apabila mampu mendiskusikan permasalahan yang berhubungan dengan perilaku seksual dan kesehatan reproduksi dengan teman sebaya daripada orangtua, hal itu karena kelompok sebaya dianggap memiliki kesetaraan pengetahuan. Di dalam kelompok sebaya kental dengan budaya kesetiakawanan sosial, yaitu permasalahan seorang teman juga merupakan permasalahan teman yang lain. Apabila salah seorang dari mereka mempunyai informasi tertentu, ada keinginan agar teman sebayanya yang lain juga mengetahuinya, termasuk informasi kesehatan reproduksi dan juga seks. Segala informasi yang mereka peroleh, baik dari media cetak, media elektronik, pengalaman pribadi ataupun bisikbisik teman, akan cenderung dikomunikasikan kepada teman sebayanya. Remaja akan merasa lebih aman, lebih terbuka, serta bebas untuk dapat membicarakan masalah seksualitas dan kesehatan reproduksi kepada teman sebayanya. Teman sebaya lebih dapat menerima perbedaan pendapat dan memenuhi kebutuhan remaja daripada orang dewasa karena di antara mereka sudah saling mengenal, sering bertemu, saling bebas, dan terbuka. ${ }^{12}$

Penelitian sebelumnya menunjukkan tidak terdapat korelasi antara sumber informasi dan perilaku dalam kesehatan reproduksi, hal ini sejalan dengan penelitian ini. ${ }^{12}$ Pondok pesantren salafiyah merupakan model pondok pesantren yang tertutup dari lingkungan luar. Sumber 
informasi yang dapat diakses oleh remaja putri di pondok pesantren hanya terbatas. Mereka tidak dapat bebas melihat televisi, mendengarkan radio, ataupun mengakses internet. Sumber informasi yang dapat diperoleh adalah dari guru/ustadzah, orangtua, teman sebaya, dan kitab klasik yang diajarkan di pondok pesantren.

Disarankan edukasi teman sebaya mengenai kesehatan reproduksi remaja perlu diterapkan dalam pondok pesantren untuk peningkatan pengetahuan kesehatan reproduksi. Skrining dan konseling kesehatan reproduksi remaja harus dilakukan oleh tenaga kesehatan pada remaja di pondok pesantren.

Simpulan, masalah kesehatan reproduksi di pondok pesantren masih tinggi. Pengetahuan yang tinggi akan berdampak pada kesehatan reproduksi remaja putri di pondok pesantren. Sikap yang baik pada reproduksi akan berdampak pula terhadap baiknya kesehatan reproduksi remaja putri di pondok pesantren. Komunikasi orangtua, komunikasi guru, dan sumber informasi tidak mempunyai hubungan dengan kesehatan reproduksi remaja putri di pondok pesantren. Komunikasi teman sebaya merupakan faktor yang paling berhubungan dengan kesehatan reproduksi remaja putri di pondok pesantren.

\section{Daftar Pustaka}

1. Aisyaroh N. Kesehatan reproduksi remaja. J Majalah Ilmiah Sultan Agung. 2011;123(49):71-84.

2. Suryoputro A, Ford NJ, Shaluhiyah Z. Faktorfaktor yang mempengaruhi perilaku seksual remaja di Jawa Tengah: implikasinya terhadap kebijakan dan layanan kesehatan seksual dan reproduksi. Makara Kesehatan. 2006;10(1):29-40.

3. Dhamayanti M. Penyalahgunaan dan ketergantungan narkotika, alkohol dan zat adiktif (NAZA) pada remaja. MKB. 2007;39(3):142-8.

4. Zazin N, Umiarso. Pondok pesantren: sebuah lembaga Islam. Dalam: Ichwan
MN, penyunting, Pesantren di tengah arus mutu pendidikan menjawab problematika kontemporer manajemen mutu pesantren. Semarang: Rasail Medika Group; 2011. hlm 14-7, 22-37.

5. Ma'rufi I, Keman S, Notobroto HB. Faktor sanitasi lingkungan yang berperan terhadap prevalensi penyakit scabies studi pada santri di pondok pesantren kabupaten Lamongan. J Kesehatan Lingkungan. 2005;2(1):11-8.

6. Tegegn A, Yazachew M, Gelaw Y. Reproductive health knowledge and attitude among adolescents: a community based study in Jimma Town, Southwest Ethiop. Ethiop J Health Dev. 2008;22(3):140-51.

7. Cahyo K, Kurniawan TP, Margawati A. Faktor-faktor yang mempengaruhi praktik kesehatan reproduksi remaja di SMA Negeri 1 kabupaten Purbalingga. J Promosi Kesehatan Indonesia. 2008;3(2):86-101.

8. Bobhate P, Shrivastava S. A cross sectional study of knowledge and practices about reproductive health among female adolescentsinan urban slum of Mumbai.J Fam Reproductive Health. 2011;5(4):117-24.

9. Malleshappa K, Krishna S, Nandini C. Knowledge and attitude about reproductive health among rural adolescent girls in Kuppam mandal: an intervention study. Biomed Res. 2011;22(3):305-10.

10. Asfriyati, Sanusi SR. Gambaran karakteristik, keluarga, dan perilaku seksual santri di Pesantren Purba Baru. J Komunikasi Penelitian. 2006;18(1):1-4.

11. Suminar MCR, Dharminto, Dharmawan Y. Korelasi sumber informasi media dan lingkungan pergaulan dengan perilaku seksual remaja dalam berpacaran (studi kasus pada siswa kelas XI di satu SMA kota Surakarta tahun 2012). JKM. 2012;1(2):187-205.

12. Imron A. MDGs dan kesehatan reproduksi remaja. Dalam: Sandra M, penyunting, Pendidikan kesehatan reproduksi remaja peer educator dan efektivitas program PIKKRR di sekolah. Yogyakarta: Ar-Ruzz Media; 2012. hlm. 21-4, 40-2. 